\title{
Transcriptional Regulation of the Y-Linked Mammalian Testis-Determining Gene SRY
}

\author{
Naoki Okashita Makoto Tachibana \\ Graduate School of Frontier Biosciences, Osaka University, Osaka, Japan
}

\section{Keywords}

Disorders of sexual development - Epigenetic modifier . Gene expression · Gonadal differentiation · SRY · Testis development . Transcription factor

\begin{abstract}
Mammalian male sex differentiation is triggered during embryogenesis by the activation of the Y-linked testis-determining gene $S R Y$. Since insufficient or delayed expression of $S R Y$ results in $X Y$ gonadal sex reversal, accurate regulation of $S R Y$ is critical for male development in $X Y$ animals. In humans, dysregulation of $S R Y$ may cause disorders of sex development. Mouse Sry is the most intensively studied mammalian model of sex determination. Sry expression is controlled in a spatially and temporally stringent manner. Several transcription factors play a key role in sex determination as transacting factors for Sry expression. In addition, recent studies have shown that several epigenetic modifications of Sry are involved in sex determination as cis-acting factors for Sry expression. Herein, we review the current understanding of transcription factor- and epigenetic modifier-mediated regulation of SRY/Sry expression.

(c) 2021 S. Karger AG, Basel
\end{abstract}

\section{Introduction}

Sex differentiation plays an indispensable role not only in the inheritance of genomic information but also in the generation of genomic diversity in sexually reproducing organisms. The first step of the sex differentiation process is sex determination, which fixes the fate of sexually undifferentiated gonads to develop into either testes or ovaries. Mammalian sex is determined genetically; the presence of the sex-determining gene, $S R Y$, leads to testis development, whereasitsabsenceleads to ovarydevelopment. SRY/Sry was first discovered in humans and mice in 1990 [Gubbay et al., 1990; Sinclair et al., 1990]. XX mice carrying a transgene of a genomic fragment containing only the Sry gene developed testes, revealing that Sry alone is sufficient and that other Y chromosomal genes are not required for male sex determination [Koopman et al., 1991].

$S R Y$ is a member of the $S O X$ ( $S R Y$-like box) gene family. SRY protein can bind DNA with its high-mobility group (HMG) box and acts as a transcription factor. SRY directly binds to the enhancer of Sox9 and activates its transcription [Sekido and Lovell-Badge, 2008; Gonen et

\footnotetext{
Karger
} 


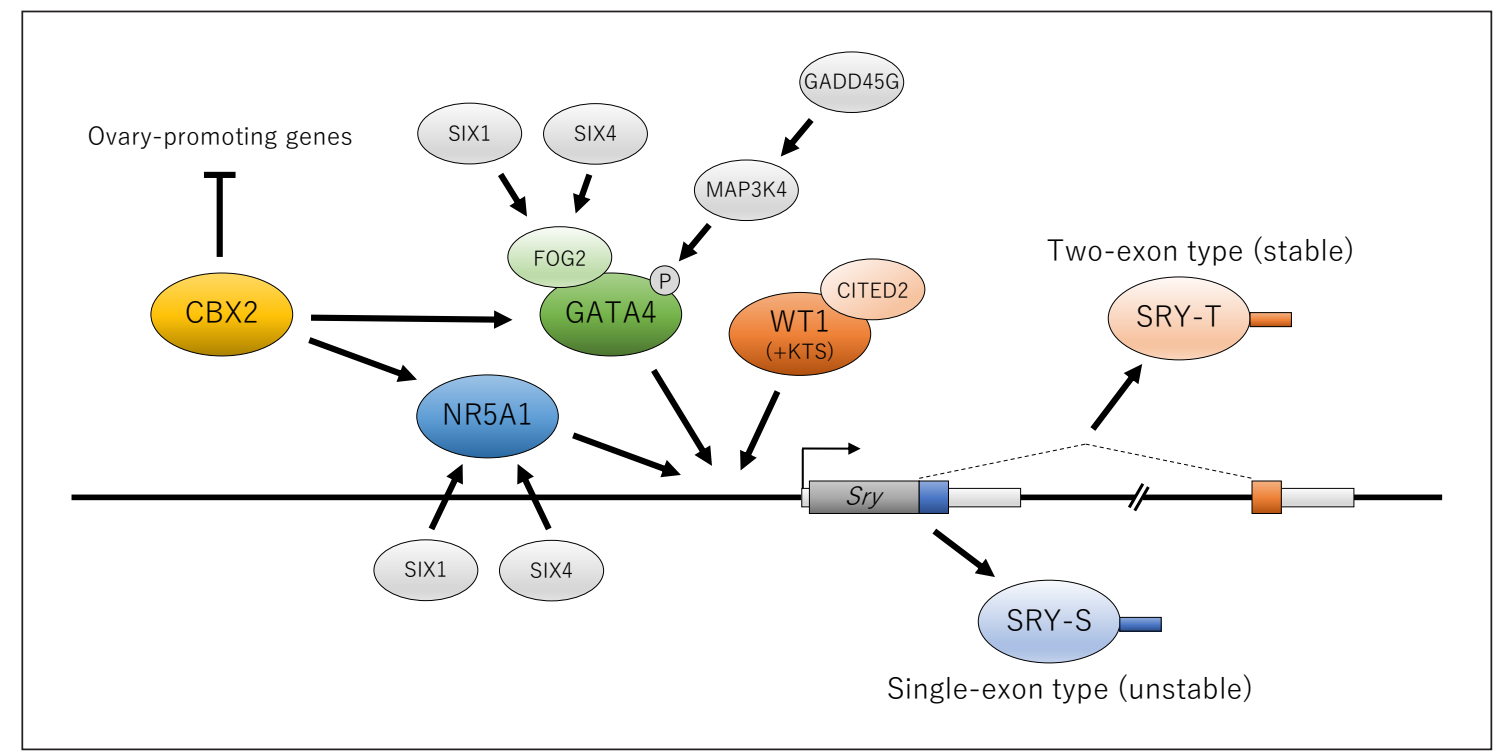

Fig. 1. Transcription factor-mediated regulation of Sry expression. The mouse Sry locus encodes 2 SRY isoforms: single-exon-type SRY (SRY-S), which carries a C-terminal degron, and 2-exon-type SRY (SRY-T), which is degron-free. Nuclear receptor transcription factor NR5A1, zinc finger transcription factor GATA4/FOG2 complex, and zinc finger transcription factor WT1 play fundamental roles in Sry activation. Several studies have indicated that these 3 transcription factors directly bind to the Sry promoter. CBX2 contributes to testis development in 2 ways: it upregulates $\mathrm{Nr} 5 \mathrm{al}$ and Gata4 expression and suppresses ovary-promoting genes. SIX1 and SIX4 positively regulate $\mathrm{Nr} 5 \mathrm{a} 1$ and Gata4 expression. WT1 acts cooperatively with a transcription factor, CITED2. GADD45G contributes to Sry expression by promoting GATA4 phosphorylation.

al., 2017, 2018]. It has been shown that the human SRY protein binds to the $(\mathrm{A} / \mathrm{T}) \mathrm{ACAA}(\mathrm{T} / \mathrm{A})$ sequence in the minor groove of DNA through its HMG box and induces DNA bending at $60-80^{\circ}$. As most human XY females carry mutations in the HMG box, the DNA-binding activity of SRY seems to be essential for sex determination [Harley and Goodfellow, 1994].

SOX 3 is a member of the SOX gene family and encodes a protein that is most similar to SRY [Bowles et al., 2000]. $S O X 3$ is a single-exon gene and is considered the ancestor of SRY [Stevanovic et al., 1993; Sutton et al., 2011]. Accordingly, all previously characterized eutherian SRY genes have been single exons. However, in mice, the second exon of Sry was discovered in 2020 [Miyawaki et al., 2020]. The 2-exon-type Sry transcript encodes a previously unidentified SRY protein (SRY-T). Mice lacking SRY-T but still expressing canonical single-exon-type SRY (SRY-S) exhibit male-to-female sex reversal. This result indicates that SRY-T is essential for male sex determination whereas SRY-S alone is insufficient for male sex determination. SRY-S and SRY-T have similar HMG boxes and poly-glutamine sequences but different C-terminal sequences, owing to the presence and absence of splicing, respectively. The C-terminal sequence of SRY-S was found to be a protein degradation motif, whereas that of SRY-T was degron-free (Fig. 1). The second exon of Sry seems to have evolved recently in mice, resulting in the emergence of a sex-determining factor resistant to protein degradation.

The mouse is a model animal in which mammalian sex determination has been most extensively studied. In mice, Sry expression is strictly controlled in a cell typeand temporal-specific manner. Sry is expressed exclusively in the precursors of Sertoli cells (pre-Sertoli cells). Other types of gonadal somatic cells and germ cells do not express Sry. Sry expression starts at embryonic day 10.5 (E10.5) [Koopman et al., 1990; Hacker et al., 1995; Jeske et al., 1996]. Sry is detected only in the central region of the genital ridges in the early stages of expression [Bullejos and Koopman, 2001; Wilhelm et al., 2005]. Sry expression extends to the whole region of the genital ridges at about E11.5 and is extinguished by E12.5. When the Y chromosome of Mus poschiavinus (Ypos) was introduced into the C57BL/6J (B6) autosomal background, the corresponding XY mice developed ovotestes, gonads containing both ovarian and testicular tissue [Eicher et al., 1982]. The expression peak of Sry in XY B6 (Ypos) gonads is delayed by up to $10 \mathrm{~h}$ compared with that of control XY 
B6 gonads [Bullejos and Koopman, 2005], indicating the importance of the time window of Sry expression in inducing Sertoli cell differentiation. Interestingly, a recent whole-genome sequence analysis of a certain colony of XY B6 (Ypos) has revealed that a variant region on chromosome 13 , that is not derived from $\mathrm{B} 6$, protects against XY gonadal sex reversal [Livermore et al., 2020]. A transgenic mouse study further confirmed that a narrow time window of Sry expression is critical for inducing Sertoli cell differentiation. Hiramatsu et al. [2009] have established mouse lines carrying Sry transgenes whose expression is driven by the promoter of heat shock protein 70.3 (Hsp70.3-Sry). In this system, Sry expression was induced experimentally at various time points, revealing that only a 6 h delay in Sry induction results in a failure to initiate testis development [Hiramatsu et al., 2009]. In contrast to mouse Sry, SRY in other mammals such as human [Clepet et al., 1993], bovine [Daneau et al., 1995], goat [MontazerTorbati et al., 2010], rats [Turner et al., 2007], and marsupials [Harry et al., 1995] are expressed more broadly.

It is likely that timely and spatially accurate induction of $S R Y$ is critical for mammalian male development other than that of mice. Differences of disorders of sex development (DSDs) in humans are accompanied by atypical conditions of external or internal sexual organs [Bashamboo and McElreavey, 2016; Audi et al., 2018]. Genetic screening of human patients exhibiting XY gonadal dysgenesis has led to the identification of several types of transcription factors that potentially regulate $S R Y$ expression. Indeed, genetic and biochemical approaches using knockout/transgenic mice have demonstrated that multiple transcription factors are involved in Sry regulation. Current evidence shows that Sry expression is also controlled in an epigenetic manner, at least in mice. Herein, we discuss transcription factor- and epigenetic modifiermediated regulation of Sry expression, which were mainly obtained from mouse genetic studies.

\section{Transcription Factor-Mediated Regulation of Sry Expression}

Transcription factors are proteins that bind to specific DNA sequences and, in turn, upregulate or downregulate the expression of the adjacent genes. Transcription factors are grouped into classes based on the structure of their DNA-binding domains. As Sry expression is prolonged in the XY gonads lacking SOX9 [Chaboissier et al., 2004; Barrionuevo et al., 2006], SOX9 may play a role in the downregulation of Sry. Herein, we describe the fun-

Transcription Factor- and Epigenetic Modifier-Mediated Regulation of Sry damental roles of a nuclear receptor family transcription factor and 2 zinc finger transcription factors in the upregulation of Sry (Fig. 1).

\section{Nuclear Receptor Transcription Factor, NR5A1}

NR5A1, previously known as SF-1 or AD4BP, contains several domains typically conserved in other nuclear receptor family proteins, such as the N-terminal DNAbinding domain and C-terminal ligand-binding domain. NR5A1 is considered an orphan nuclear receptor protein. Historically, NR5A1 was identified by screening for proteins with the capacity to activate transcription from $\mathrm{P} 450$ steroidogenic enzyme promoters [Lala et al., 1992; Morohashi et al., 1992]. NR5A1 has multiple functions in sex development, such as steroid synthesis [Morohashi et al., 1992], gonadal development [Luo et al., 1994], and activation of Sox9 [Sekido and Lovell-Badge, 2008]. In humans, mutations in NR5A1 have been found to cause XY sex reversal [Achermann et al., 1999]. NR5A1 binding sites have been identified in $S R Y$ promoters in pigs [Pilon et al., 2003]. Furthermore, reporter expression analysis has demonstrated that these NR5A1-binding sites in the pig $S R Y$ locus are necessary for SRY activation. NR5A1-binding sites in the mouse Sry locus have not been identified.

The expression of Nr5al in gonadal somatic cells is regulated by multiple molecular pathways. Mutation of CBX2 (also called M33), a component of polycombgroup repressive complex 1 (PRC1), causes XY sex reversal in humans and mice [Katoh-Fukui et al., 1998; BiasonLauber et al., 2009]. Embryonic gonads lacking CBX2 exhibit reduced expression of $\mathrm{Nr} 5 \mathrm{al}$ [Katoh-Fukui et al., 2012 ]. This result indicates that CBX2 positively regulates $\mathrm{Nr} 5 \mathrm{a} 1$ expression. An alternative function of CBX2 in sex development is the epigenetic suppression of ovary-determining genes, thereby blocking testis development [Garcia-Moreno et al., 2019]. PRC1-mediated epigenetic regulation of sex development is discussed below. Mice lacking the homeobox transcription factors SIX1 and SIX4 exhibit perturbed Sry expression and male-to-female sex reversal [Fujimoto et al., 2013]. SIX1 and SIX4 are involved in the upregulation of Nr5al expression in developing gonads.

\section{Zinc Finger Transcription Factors GATA4/FOG2 and WT1 \\ GATA4/FOG2 \\ GATA4 is a transcription factor with 2 zinc finger do-} mains. Mouse genetic studies have shown that conditional depletion of Gata4 at E10.5, but not at later stages, induces XY sex reversal [Manuylov et al., 2011]. In humans, 


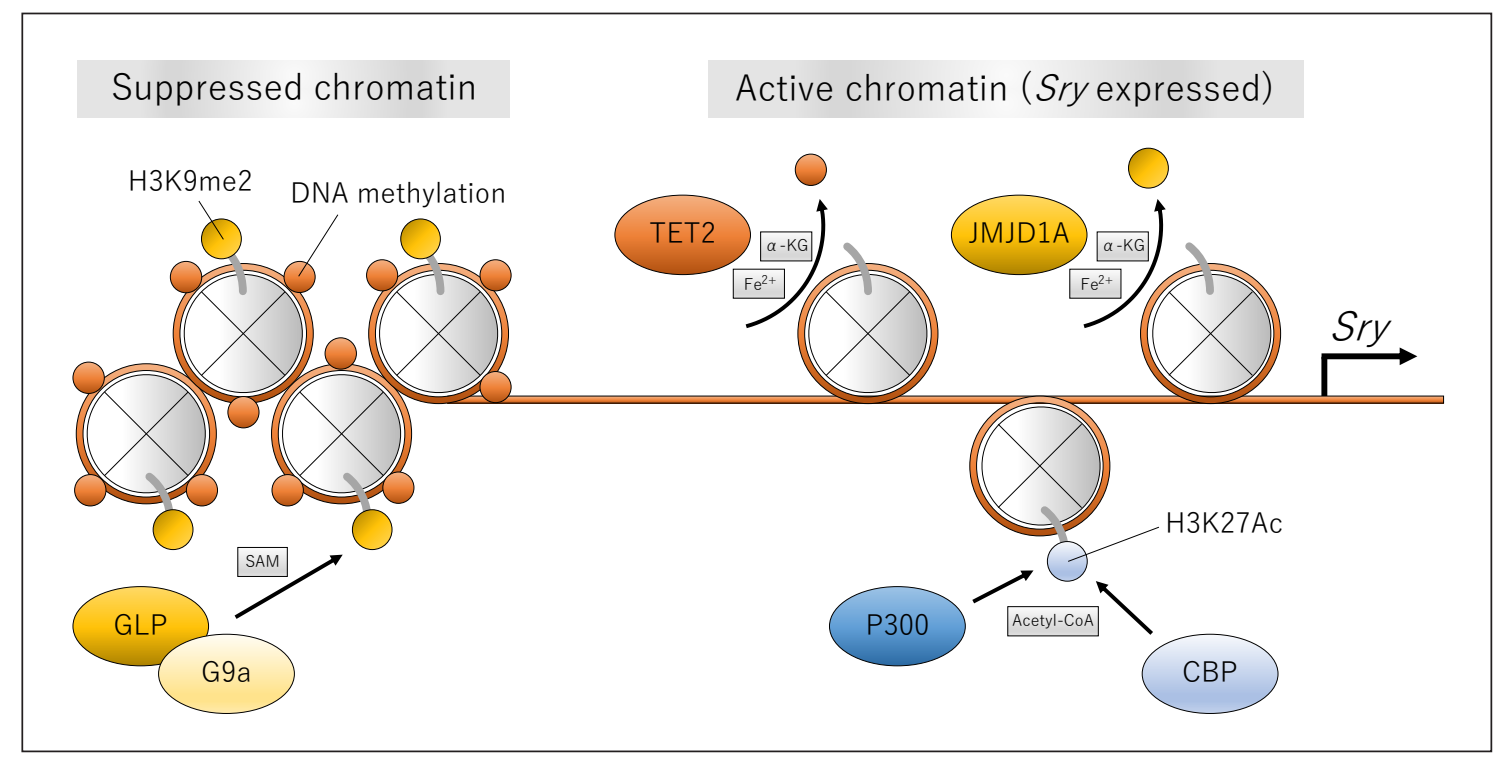

Fig. 2. Epigenetic modifier-mediated regulation of Sry expression. H3K9me2 is a representative epigenetic mark of transcriptionally suppressed chromatin. The G9a/GLP complex is responsible for depositing H3K9me2 at the Sry promoter. CpG sequences at the Sry promoter are also methylated when Sry is silent. JMJD1A upregulates Sry expression by removing H3K9me2 at the Sry promoter against G9a/GLP complex-mediated H3K9 methylation. TET2 actively demethylates CpG sequences at the Sry promoter by hydroxylating methylated cytosine. JMJD1A and TET2 utilize $\mathrm{Fe}^{2+}$ and $\alpha-\mathrm{KG}$ for the demethylation reaction. Histone acetyltransferases CBP and p300 synergistically upregulate Sry expression by acetylating H3K27 at the Sry promoter. CBP and p300 utilize acetyl$\mathrm{CoA}$ as a donor of the acetyl group.

a heterozygous missense mutation in the first zinc finger domain was found in patients with XY DSD [Lourenco et al., 2011]. Chromatin immunoprecipitation analysis has confirmed that GATA4 directly binds to the proximal promoter of Sry, which contains the consensus binding sites of GATA4 in mouse gonads [Gierl et al., 2012]. FOG2, also known as ZFPM2, is a zinc finger protein that forms a heterodimer with GATA family proteins. Interaction between GATA4 and FOG2 is required for Sry expression in mice [Tevosian et al., 2002]. Gata4 expression in developing gonads is positively regulated by CBX2 [Katoh-Fukui et al., 2012]. Furthermore, SIX1 and SIX4 contribute to Fog2 expression during the sex-determination process [Fujimoto et al., 2013].

The MAPK signaling pathway is involved in Sry activation. A forward genetic screen in mice indicated that a mutation in the gene encoding MAP3K4 (also known as MEKK4) induces a reduction in Sry expression and maleto-female reversal in mice [Bogani et al., 2009]. In humans, mutations of MAP3K4-related related protein MAP3K1 lead to XY gonadal dysgenesis [Pearlman et al., 2010]. A stress-response protein, GADD45G, binds to and activates MAP3K4, thereby promoting the phosphorylation of p38 MAPK [Takekawa and Saito, 1998; Lu et al., 2001]. Mice deficient in GADD45G also display male-to-female sex reversal [Gierl et al., 2012; Warr et al., 2012]. The loss of GADD45G, as well as the loss of MAP3K4, results in reduced phosphorylation levels of GATA4 [Warr et al., 2012]. These results suggest that MAPK signaling upregulates Sry expression through the phosphorylation of GATA4. The combined loss of insulin receptor family proteins induces male-to-female sex reversal with reduced expression of Sry [Nef et al., 2003]. As the expression levels of Gadd45g and p38 $\beta$ are perturbed in gonads lacking insulin receptor and insulin-like growth factor 1, a cross-talk between insulin signaling and MAPK signaling in Sry regulation might exist [Pitetti et al., 2013].

\section{WT1}

WT1 is a transcription factor that carries 4 zinc finger domains. Frasier syndrome patients with male pseudohermaphroditism exhibit reduced expression of WT1(+KTS), an isoform of WT1 [Barbaux et al., 1997]. Loss of WT1(+KTS) in mice also results in the failure of testis development accompanied by reduced expression of Sry [Hammes et al., 2001]. WT1 can bind to the promoter region of $S R Y$ and upregulate its expression in hu- 
mans [Hossain and Saunders, 2001]. Reporter expression analysis using HeLa cells has shown that WT1 and GATA4 synergistically enhance the transcription of mouse, pig, and human $S r y / S R Y$ promoter constructs [Miyamoto et al., 2008]. It has been proposed that WT1 cooperates with the transcription cofactor CITED2 in sex determination [Buaas et al., 2009]. There are 2 regions in the proximal 2 $\mathrm{kb}$ of the mouse Sry 5 region ( -132 to +14 and -1992 to -1897 from TSS of mouse Sry) that show moderate homology with human $S R Y 5^{\prime}$ region [Hacker et al., 1995]. A DNA-binding assay has demonstrated that the WT1binding site is located within the former region [Miyamoto et al., 2008].

\section{Epigenetic Modifier-Mediated Regulation of Sry Expression}

Epigenetics is defined as the study of gene regulation with no change in the DNA sequence. Accurate gene regulation generally depends not only on the function of transcription factors but also on chromatin structure. DNA and histones undergo covalent modifications, thereby changing the chromatin structure. Players in epigenetic modifications are categorized as writers (enzymes depositing modifications), readers (proteins that bind and decode modifications), and erasers (enzymes removing modifications) [Biswas and Rao, 2018]. The levels of epigenetic modification can fluctuate because of the opposing activities of writers and erasers. This mechanism allows the tuning of gene activity in response to environmental stimuli. Accordingly, numerous studies have demonstrated that the levels of epigenetic modifications change dynamically during mammalian development. These dynamic changes contribute to cell fate decisions and cellular differentiation. Recently, a compelling body of evidence regarding the indispensable role of epigenetic regulation in sex determination/differentiation has been accumulated. In this section, we provide an overview of the current knowledge about the role of epigenetic regulation in Sry expression (Fig. 2).

\section{H3K9 Demethylation}

Histone 3 on lysine 9 (H3K9) methylation is generally enriched in transcriptionally inactive "closed" chromatin, which is called heterochromatin. JmjC domain-containing histone demethylase JMJD1A (also called KDM3A/JHDM2A/TSGA) removes the methyl group from di-methylated H3K9 (H3K9me2) [Yamane et al., 2006]. Mice lacking JMJD1A exhibit male-to-female sex reversal
[Kuroki et al., 2013]. JMJD1A protein is predominantly detected in gonadal somatic cells but not in mesonephric cells in embryos at E11.5. A recent single-cell RNA sequencing analysis demonstrated that Jmjd1 $a$ and Sry exhibit similar expression patterns during gonadal differentiation; their mRNAs are expressed specifically in preSertoli cells [Stevant et al., 2018]. JMJD1A deficiency did not change the number of NR5A1-expressing cells per gonad but reduced the number of SRY-expressing cells per gonad to approximately $25 \%$ of that in the control. The subpopulation of JMJD1A-deficient mice showed a partial sex reversal phenotype with a testis and an ovary. These results indicate that the number of SRY-expressing cells in JMJD1A-deficient gonads at E11.5 may be near the threshold of the cell number required for inducing testis development. ChIP analysis demonstrated that JMJD1A accumulates at the Sry locus in pre-Sertoli cells. Furthermore, loss of JMJD1A results in an increase in the H3 K9me2 modification at the Sry locus. These results indicate that JMJD1A catalyzes H3K9 demethylation at the Sry locus [Kuroki et al., 2013].

There are multiple $\mathrm{H} 3 \mathrm{~K} 9$-methylating enzymes in mammalian cells [Hyun et al., 2017]. There should be an H3 K9-methylating enzyme that acts in opposition to JMJD1A-mediated H3K9 demethylation at the Sry locus. G9a (also called EHMT2) and its related molecule GLP (also known as EHMT1) exhibit an intrinsic methyltransferase activity toward H3K9 [Tachibana et al., 2002, 2005]. GLP and G9a exist as heterodimers in vivo; this heterodimer formation is essential for the $\mathrm{H} 3 \mathrm{~K} 9$-methylating activity [Tachibana et al., 2008]. Heterozygous mutation of GLP reduced H3K9 hypermethylation at the Sry locus in JMJD1A-deficient gonads, indicating that the GLP/G9a complex is responsible for hypermethylation of H3K9me2 in JMJD1A-deficient gonads [Kuroki et al., 2017]. Furthermore, perturbed Sry expression in JMJD1A-deficient embryos and the sex-reversal phenotype in JMJD1A-deficient mice were rescued by GLP heterozygous mutation. These results show that GLP/G9a suppresses Sry by methylating H3K9 at the Sry locus.

\section{Histone Acetylation}

Histone acetylation is enriched in transcriptionally active "open" chromatin. Histone acetyltransferases (HATs) and histone deacetylases (HDACs) play critical roles in controlling histone acetylation levels. The cAMP-response-element-binding protein (CREB)binding protein p300 (EP300/KAT3B) and CBP (CREBBP/KAT3A) are 2 members of the KAT3 subfamily of HATs [Dancy and Cole, 2015]. There is a pos- 
itive correlation between H3K9/K27 acetylation and Sry expression in developing gonads [Gierl et al., 2012; Carre et al., 2018]. XY mice deficient in CBP or p300 show a partial male-to-female sex reversal phenotype, whereas those deficient in both enzymes show a complete sex reversal phenotype [Carre et al., 2018]. mRNA expression analysis revealed an approximately 6-fold reduction in Sry expression in gonads lacking CBP/ p300. ChIP analysis demonstrated that the level of $\mathrm{H} 3 \mathrm{~K} 27 \mathrm{ac}$ was reduced at the Sry promoter in E11.5 gonads lacking $\mathrm{CBP} / \mathrm{p} 300$, suggesting that $\mathrm{H} 3 \mathrm{~K} 27 \mathrm{ac}$ might play a pivotal role in Sry activation. In contrast, the levels of pan-H3ac and $\mathrm{H} 3 \mathrm{~K} 9 \mathrm{ac}$ were unaffected in E11.5 gonads lacking $\mathrm{CBP} / \mathrm{p} 300$, indicating that other unidentified HATs are responsible for histone $\mathrm{H} 3$ acetylation other than H3K27ac at the Sry locus.

The K136 residue of the human SRY protein can be acetylated by p300 [Thevenet et al., 2004]. Acetylation of SRY enhances its nuclear localization by increasing its interaction with importin-beta. On the other hand, deacetylation of K136 by HDAC3 stimulates cytoplasmic localization of SRY. Exome sequencing analysis revealed mutations in human CBP and $p 300$ in DSD patients with 46,XY gonadal dysgenesis [Bagheri-Fam et al., 2015; Eggers et al., 2016], suggesting that the role of $\mathrm{CBP} / \mathrm{p} 300$ in male sex development might be conserved in mice and humans.

\section{Polycomb Group-Mediated Gene Silencing}

Polycomb group proteins are a family of protein complexes, first discovered in fruit flies, that silence developmental genes, including Hox cluster genes. Polycomb group proteins are classified into 1 of 2 multiprotein complexes, PRC1 and PRC2 [Aloia et al., 2013]. PRC1 and PRC2 catalyze the ubiquitination of H2AK119 and methylation of $\mathrm{H} 3 \mathrm{~K} 27$, respectively. CBX2 is a core component of PRC1. CBX2 is thought to be responsible for targeting PRC1 to chromatin through specific binding to H3K9me3 and H3K27me3 [Kaustov et al., 2011]. Transcriptomic and immunohistochemical analyses demonstrated that Sry and Sox9 expression is downregulated in CBX2-deficient gonads. Furthermore, the expression levels of genes essential for gonadal development, such as Lhx9, Nr5a1, Dax1/Nr0b1, Gata4, Arx, and Dmrt1, were also perturbed in $\mathrm{Cb} \times 2$-deficient gonads [Katoh-Fukui et al., 2012]. These results suggest that CBX2 is an activator of testis-promoting genes.

Among a cohort of human DSD patients, a 46,XY girl with normal female genitalia, uterus, and ovarianlike tissue carried double heterozygous alleles for $C B X 2$
[Biason-Lauber et al., 2009]. Each of the alleles corresponded to the missense mutations CBX2:P98L and $\mathrm{R} 443 \mathrm{P}$. In vitro transfection experiments demonstrated that these mutations influence the ability of CBX2 to bind to the NR5A1 promoter region and activate NR5A1 expression. Accordingly, mouse embryonic gonads lacking CBX2 failed to activate Nr5a1 [Katoh-Fukui et al., 2012].

Another possible function of CBX2 in sex determination has recently been proposed. Testis- and ovary-promoting genes are initially co-expressed in XX and XY gonads prior to sex determination and are bivalently marked by H3K4me3 and H3K27me3 [Garcia-Moreno et al., 2019]. XY sex-reversal caused by $C b \times 2$ mutation was repaired by an additional mutation of Wnt4, an ovary-promoting gene. Furthermore, Sry expression was restored in XY Cbx2/Wnt4 double-mutant mice. These findings suggest that CBX2 stabilizes testis fate by suppressing ovary-promoting genes, which accords well with the general function of PRC1 as the negative regulator of transcription.

\section{DNA Demethylation}

DNA methylation occurs predominantly on cytosine residues, followed by guanine residues (CpG). DNA methylation is catalyzed by the de novo DNA methyltransferases DNMT3A/DNMT3B and is maintained by DNA methyltransferase DNMT1 during DNA replication.

It has been reported that the CpG sequences of the Sry promoter are demethylated in gonadal somatic cells during the sex-determination period. These observations show that DNA demethylation in the Sry promoter precedes the onset of Sry expression and that DNA demethylation is more prominent in the Sry promoter region than in other regions of the Sry locus [Nishino et al., 2004; Gierl et al., 2012]. In vitro promoter activity analysis demonstrated that methylation of the $5^{\prime}$-flanking region suppresses the activity of a Sry reporter plasmid [Nishino et al., 2004]. The non-CpG (CCTGG) sequence in the Sry locus is also demethylated during the sex-determination period [Nishino et al., 2011].

CpG methylation marks can be removed by replication-dependent and -independent mechanisms. The former is regulated by inhibition of DNA methyltransferase activity during de novo DNA synthesis, whereas the latter (also known as active demethylation) is induced by the oxidation of 5-methylcytosine ( $5 \mathrm{mC}$ ) by 10-11 translocation proteins (TET1/TET2/TET3), which produce 5-hydroxymethylcytosine $(5 \mathrm{hmC}) .5 \mathrm{hmC}$ is further oxidized 
to 5-formylcytosine (5fC) and 5-carboxycytosine (5caC) by TET enzymes, both of which can be repaired by the base excision repair pathway to produce unmodified cytosine [Wu and Zhang, 2010]. 5hmC is highly enriched in male gonadal somatic cells during the sex-determination period [Okashita et al., 2019]. The $5 \mathrm{hmC}$ level increases in the Sry promoter concomitantly with Sry expression in gonadal somatic cells. Deficiency in TET2, but not TET1 and TET3, induces an increase in DNA methylation and the disappearance of $5 \mathrm{hmC}$ in the Sry promoter. Furthermore, TET2 deficiency enhances the sex reversal phenotype of Jmjdla-deficient mice [Okashita et al., 2019]. These results reveal that TET2-mediated active DNA demethylation is involved in the regulation of Sry expression and male sex determination. Cloned canines generated by somatic cell nuclear transfer (SCNT) occasionally show male-to-female sex reversal. Reduced Sry expression and hypermethylation of the Sry locus have been observed in SCNT-derived XY gonads showing the DSD phenotype [Jeong et al., 2016]. These data suggest that incomplete demethylation of Sry can cause XY DSD in dogs.

In a case of human XY gonadal dysgenesis, the chromosome $\mathrm{Y}$ inversion juxtaposed SRY-containing euchromatin to the Yq12 heterochromatin, resulting in the silencing of $S R Y$ [Gimelli et al., 2006]. The CpG sequence located $3 \mathrm{~kb} 5^{\prime}$ of $S R Y$ in this patient was methylated twice as much as that of her father, who showed mosaicism of a normal Y chromosome and several different rearrangements. These results suggest that the level of DNA methylation may be important for $S R Y$ expression in humans.

\section{Perspective}

As described, recent mouse genetic studies have revealed the fundamental role of epigenetic regulation in Sry expression. In addition, evidence that the cellular metabolic state can alter the cellular epigenetic state has been accumulated [Reid et al., 2017]. In this scenario, alteration of metabolism can change gene expression epigenetically by modulating the substrates or cofactors of chromatin-modifying enzymes. In this section, we discuss the possible involvement of metabolic pathways in epigenetic gene regulation by referring to previous studies.

Intermediate metabolites utilized in epigenetic gene regulation are summarized in Figure 2. DNA and histone methyltransferases utilize $\mathrm{S}$-adenosyl methionine
(SAM) as a methyl donor. The reaction of histone demethylation by JmjC domain-containing enzymes and DNA demethylation by TET family enzyme DNA hydroxylaseareboth dependenton $\mathrm{Fe}^{2+}$ and $\alpha$-ketoglutarate $(\alpha-K G)$. Acetyl coenzyme A (acetyl-CoA) is a universal donor for acetylation reactions in eukaryotes. It was presented that a variety of metabolites and the corresponding metabolic enzymes can modulate epigenetic modification levels and influence gene expression [Wolff et al., 1998; Wellen et al., 2009; Sutendra et al., 2014; Carey et al., 2015; Mews et al., 2017; Wang et al., 2020]. However, the relationship between metabolism and sex determination/differentiation remains elusive. Interestingly, 3-hydroxy-3-methylglutaryl coenzyme A synthase 2 (HMGCS2), encoding a metabolic enzyme for energy production from fatty acids, shows a very similar pattern as Sry in developing gonads [BagheriFam et al., 2020]. Further, Sry activation initiates glycogenesis in pre-Sertoli cells, suggesting the importance of glucose metabolism for SRY/SOX9-downstream events in gonadal sex determination [Matoba et al., 2005, 2008]. More than half of human DSDs cannot be explained by alterations in the genes that are known to be required for sex determination or gonadal development [Munger and Capel, 2012]. It is possible that both genetic and epigenetic mutations during embryogenesis are responsible for the onset of DSDs.

\section{Acknowledgement}

We thank all members of the Tachibana laboratory for helpful assistance.

\section{Conflict of Interest Statement}

The authors declare no competing financial interests.

\section{Funding Sources}

This work was supported by KAKENHI from the Japan Society for the Promotion of Science (JSPS) 17H06424 (M.T.)

\section{Author Contributions}

M.T. designed the content of the manuscript. N.O. and M.T. wrote the manuscript. 


\section{References}

Achermann JC, Ito M, Ito M, Hindmarsh PC, Jameson JL. A mutation in the gene encoding steroidogenic factor- 1 causes XY sex reversal and adrenal failure in humans. Nat Genet. 1999;22(2):125-6.

Aloia L, Di Stefano B, Di Croce L. Polycomb complexes in stem cells and embryonic development. Development. 2013;140(12):2525-34.

Audi L, Ahmed SF, Krone N, Cools M, McElreavey $\mathrm{K}$, Holterhus PM, et al. Genetics in endocrinology: Approaches to molecular genetic diagnosis in the management of differences/ disorders of sex development (DSD): position paper of EU COST Action BM 1303 'DSDnet'. Eur J Endocrinol. 2018;179(4):R197-206.

Bagheri-Fam S, Ono M, Li L, Zhao L, Ryan J, Lai $\mathrm{R}$, et al. FGFR2 mutation in 46,XY sex reversal with craniosynostosis. Hum Mol Genet. 2015; 24(23):6699-710.

Bagheri-Fam S, Chen $\mathrm{H}$, Wilson S, Ayers K, Hughes J, Sloan-Bena F, et al. The gene encoding the ketogenic enzyme HMGCS2 displays a unique expression during gonad development in mice. PLoS One. 2020;15(1):e0227411.

Barbaux S, Niaudet P, Gubler MC, Grünfeld JP, Jaubert F, Kuttenn F, et al. Donor splice-site mutations in WT1 are responsible for Frasier syndrome. Nat Genet. 1997;17(4):467-70.

Barrionuevo F, Bagheri-Fam S, Klattig J, Kist R, Taketo MM, Englert C, et al. Homozygous inactivation of Sox 9 causes complete XY sex reversal in mice. Biol Reprod. 2006;74(1):195-201.

Bashamboo A, McElreavey K. Mechanism of sex determination in humans: insights from disorders of sex development. Sex Dev. 2016; 10(5-6):313-25.

Biason-Lauber A, Konrad D, Meyer M, DeBeaufort C, Schoenle EJ. Ovaries and female phenotype in a girl with 46,XY karyotype and mutations in the CBX2 gene. Am J Hum Genet. 2009;84(5):658-63.

Biswas S, Rao CM. Epigenetic tools (The Writers, The Readers and The Erasers) and their implications in cancer therapy. Eur J Pharmacol. 2018;837:8-24.

Bogani D, Siggers P, Brixey R, Warr N, Beddow S, Edwards J, et al. Loss of mitogen-activated protein kinase kinase kinase 4 (MAP3K4) reveals a requirement for MAPK signalling in mouse sex determination. PLoS Biol. 2009;7(9):e1000196.

Bowles J, Schepers G, Koopman P. Phylogeny of the SOX family of developmental transcription factors based on sequence and structural indicators. Dev Biol. 2000;227(2):239-55.

Buaas FW, Val P, Swain A. The transcription cofactor CITED2 functions during sex determination and early gonad development. Hum Mol Genet. 2009;18(16):2989-3001.

Bullejos M, Koopman P. Spatially dynamic expression of Sry in mouse genital ridges. Dev Dyn. 2001;221(2):201-5.

Bullejos M, Koopman P. Delayed Sry and Sox9 expression in developing mouse gonads underlies B6-Y(DOM) sex reversal. Dev Biol. 2005;278(2):473-81.
Carey BW, Finley LW, Cross JR, Allis CD, Thompson CB. Intracellular a-ketoglutarate maintains the pluripotency of embryonic stem cells. Nature. 2015;518(7539):413-6.

Carre GA, Siggers P, Xipolita M, Brindle P, Lutz B, Wells S, et al. Loss of p300 and CBP disrupts histone acetylation at the mouse Sry promoter and causes XY gonadal sex reversal. Hum Mol Genet. 2018;27(1):190-8.

Chaboissier MC, Kobayashi A, Vidal VI, Lützkendorf S, van de Kant HJ, Wegner M, et al. Functional analysis of Sox8 and Sox9 during sex determination in the mouse. Development. 2004;131(9):1891-901.

Clepet C, Schafer AJ, Sinclair AH, Palmer MS, Lovell-Badge R, Goodfellow PN. The human SRY transcript. Hum Mol Genet. 1993;2(12): 2007-12.

Dancy BM, Cole PA. Protein lysine acetylation by p300/CBP. Chem Rev. 2015;115(6):2419-52.

Daneau I, Houde A, Ethier JF, Lussier JG, Silversides DW. Bovine SRY gene locus: cloning and testicular expression. Biol Reprod. 1995; 52(3):591-9.

Eggers S, Sadedin S, van den Bergen JA, Robevska G, Ohnesorg T, Hewitt J, et al. Disorders of sex development: insights from targeted gene sequencing of a large international patient cohort. Genome Biol. 2016;17(1):243.

Eicher EM, Washburn LL, Whitney JB, Morrow KE. Mus poschiavinus $\mathrm{Y}$ chromosome in the C57BL/6J murine genome causes sex reversal. Science. 1982;217(4559):535-7.

Fujimoto Y, Tanaka SS, Yamaguchi YL, Kobayashi H, Kuroki S, Tachibana M, et al. Homeoproteins Six 1 and Six 4 regulate male sex determination and mouse gonadal development. Dev Cell. 2013;26(4):416-30.

Garcia-Moreno SA, Lin YT, Futtner CR, Salamone IM, Capel B, Maatouk DM. CBX2 is required to stabilize the testis pathway by repressing Wnt signaling. PLoS Genet. 2019; 15(5):e1007895.

Gierl MS, Gruhn WH, von Seggern A, Maltry N, Niehrs C. GADD45G functions in male sex determination by promoting p38 signaling and Sry expression. Dev Cell. 2012;23(5):1032-42.

Gonen N, Quinn A, O'Neill HC, Koopman P, LovellBadge R. Correction: Normal levels of Sox9 expression in the developing mouse testis depend on the TES/TESCO enhancer, but this does not act alone. PLoS Genet. 2017;13(1):e1006584.

Gonen N, Futtner CR, Wood S, Garcia-Moreno SA, Salamone IM, Samson SC, et al. Sex reversal following deletion of a single distal enhancer of Sox9. Science. 2018;360(6396):1469-73.

Gubbay J, Collignon J, Koopman P, Capel B, Economou A, Münsterberg A, et al. A gene mapping to the sex-determining region of the mouse $Y$ chromosome is a member of a novel family of embryonically expressed genes. $\mathrm{Na}-$ ture. 1990;346(6281):245-50.

Hacker A, Capel B, Goodfellow P, Lovell-Badge R. Expression of Sry, the mouse sex determining gene. Development. 1995;121(6):1603-14.
Hammes A, Guo JK, Lutsch G, Leheste JR, Landrock D, Ziegler $U$, et al. Two splice variants of the Wilms' tumor 1 gene have distinct functions during sex determination and nephron formation. Cell. 2001;106(3):319-29.

Harley VR, Goodfellow PN. The biochemical role of SRY in sex determination. Mol Reprod Dev. 1994;39(2):184-93.

Harry JL, Koopman P, Brennan FE, Graves JA, Renfree MB. Widespread expression of the testis-determining gene SRY in a marsupial. Nat Genet. 1995;11(3):347-9.

Hiramatsu R, Matoba S, Kanai-Azuma M, Tsunekawa N, Katoh-Fukui Y, Kurohmaru $\mathrm{M}$, et al. A critical time window of Sry action in gonadal sex determination in mice. Development. 2009;136(1):129-38.

Hossain A, Saunders GF. The human sex-determining gene SRY is a direct target of WT1. J Biol Chem. 2001;276(20):16817-23.

Hyun K, Jeon J, Park K, Kim J. Writing, erasing and reading histone lysine methylations. Exp Mol Med. 2017;49(4):e324.

Jeong YH, Lu H, Park CH, Li M, Luo H, Kim JJ, et al. Stochastic anomaly of methylome but persistent SRY hypermethylation in disorder of sex development in canine somatic cell nuclear transfer. Sci Rep. 2016;6:31088.

Jeske YW, Mishina Y, Cohen DR, Behringer RR, Koopman P. Analysis of the role of Amh and Fral in the Sry regulatory pathway. Mol Reprod Dev. 1996;44(2):153-8.

Katoh-Fukui Y, Tsuchiya R, Shiroishi T, Nakahara Y, Hashimoto N, Noguchi K, et al. Maleto-female sex reversal in M33 mutant mice. Nature. 1998;393(6686):688-92.

Katoh-Fukui Y, Miyabayashi K, Komatsu T, Owaki A, Baba T, Shima Y, et al. Cbx2, a polycomb group gene, is required for Sry gene expression in mice. Endocrinology. 2012; 153(2):913-24.

Kaustov L, Ouyang H, Amaya M, Lemak A, Nady N, Duan S, et al. Recognition and specificity determinants of the human cbx chromodomains. J Biol Chem. 2011;286(1):521-9.

Koopman P, Münsterberg A, Capel B, Vivian N, Lovell-Badge R. Expression of a candidate sex-determining gene during mouse testis differentiation. Nature. 1990;348(6300):4502.

Koopman P, Gubbay J, Vivian N, Goodfellow P, Lovell-Badge R. Male development of chromosomally female mice transgenic for Sry. Nature. 1991;351(6322):117-21.

Kuroki S, Matoba S, Akiyoshi M, Matsumura Y, Miyachi H, Mise N, et al. Epigenetic regulation of mouse sex determination by the histone demethylase Jmjdla. Science. 2013; 341(6150):1106-9.

Kuroki S, Okashita N, Baba S, Maeda R, Miyawaki S, Yano M, et al. Rescuing the aberrant sex development of H3K9 demethylase Jmjd1adeficient mice by modulating H3K9 methylation balance. PLoS Genet. 2017;13(9): e1007034. 
Lala DS, Rice DA, Parker KL. Steroidogenic factor I, a key regulator of steroidogenic enzyme expression, is the mouse homolog of fushi tarazu-factor I. Mol Endocrinol. 1992;6(8):124958.

Livermore C, Simon M, Reeves R, Stévant I, Nef $S$, Pope M, et al. Protection against XY gonadal sex reversal by a variant region on mouse chromosome 13. Genetics. 2020; 214(2):467-77.

Lourenco D, Brauner R, Rybczynska M, NihoulFekete C, McElreavey K, Bashamboo A. Lossof-function mutation in GATA4 causes anomalies of human testicular development. Proc Natl Acad Sci U S A. 2011;108(4):1597602.

Lu B, Yu H, Chow C, Li B, Zheng W, Davis RJ, et al. GADD45gamma mediates the activation of the p38 and JNK MAP kinase pathways and cytokine production in effector TH1 cells. Immunity. 2001;14(5):583-90.

Luo X, Ikeda Y, Parker KL. A cell-specific nuclear receptor is essential for adrenal and gonadal development and sexual differentiation. Cell. 1994;77(4):481-90.

Manuylov NL, Zhou B, Ma Q, Fox SC, Pu WT, Tevosian SG. Conditional ablation of Gata4 and Fog2 genes in mice reveals their distinct roles in mammalian sexual differentiation. Dev Biol. 2011;353(2):229-41.

Matoba S, Kanai Y, Kidokoro T, Kanai-Azuma M, Kawakami H, Hayashi Y, et al. A novel Srydownstream cellular event which preserves the readily available energy source of glycogen in mouse sex differentiation. J Cell Sci. 2005;118(Pt 7):1449-59.

Matoba S, Hiramatsu R, Kanai-Azuma M, Tsunekawa N, Harikae K, Kawakami H, et al. Establishment of testis-specific SOX9 activation requires high-glucose metabolism in mouse sex differentiation. Dev Biol. 2008; 324(1):76-87.

Mews P, Donahue G, Drake AM, Luczak V, Abel T, Berger SL. Acetyl-CoA synthetase regulates histone acetylation and hippocampal memory. Nature. 2017;546(7658):381-6.

Miyamoto Y, Taniguchi H, Hamel F, Silversides DW, Viger RS. A GATA4/WT1 cooperation regulates transcription of genes required for mammalian sex determination and differentiation. BMC Mol Biol. 2008;9:44.

Miyawaki S, Kuroki S, Maeda R, Okashita N, Koopman P, Tachibana M. The mouse Sry locus harbors a cryptic exon that is essential for male sex determination. Science. 2020; 370(6512):121-4.

Montazer-Torbati F, Kocer A, Auguste A, Renault L, Charpigny G, Pailhoux E, et al. A study of goat SRY protein expression suggests putative new roles for this gene in the developing testis of a species with long-lasting SRY expression. Dev Dyn. 2010;239(12):3324-35.

Morohashi K, Honda S, Inomata Y, Handa H, Omura T. A common trans-acting factor, Ad4-binding protein, to the promoters of steroidogenic P-450s. J Biol Chem. 1992;267(25): 17913-9.
Munger SC, Capel B. Sex and the circuitry: progress toward a systems-level understanding of vertebrate sex determination. Wiley Interdiscip Rev Syst Biol Med. 2012;4(4):401-12.

Nef S, Verma-Kurvari S, Merenmies J, Vassalli JD, Efstratiadis A, Accili D, et al. Testis determination requires insulin receptor family function in mice. Nature. 2003;426(6964): 291-5.

Nishino K, Hattori N, Tanaka S, Shiota K. DNA methylation-mediated control of Sry gene expression in mouse gonadal development. J Biol Chem. 2004;279(21):22306-13.

Nishino K, Hattori N, Sato S, Arai Y, Tanaka S, Nagy A, et al. Non-CpG methylation occurs in the regulatory region of the Sry gene. J Reprod Dev. 2011;57(5):586-93.

Okashita N, Kuroki S, Maeda R, Tachibana M. TET2 catalyzes active DNA demethylation of the Sry promoter and enhances its expression. Sci Rep. 2019;9(1):13462.

Pearlman A, Loke J, Le Caignec C, White S, Chin L, Friedman A, et al. Mutations in MAP3K1 cause 46,XY disorders of sex development and implicate a common signal transduction pathway in human testis determination. Am J Hum Genet. 2010;87(6):898-904.

Pilon N, Daneau I, Paradis V, Hamel F, Lussier JG, Viger RS, et al. Porcine SRY promoter is a target for steroidogenic factor 1 . Biol Reprod. 2003;68(4):1098-106.

Pitetti JL, Calvel P, Romero Y, Conne B, Truong V, Papaioannou MD, et al. Insulin and IGF1 receptors are essential for XX and XY gonadal differentiation and adrenal development in mice. PLoS Genet. 2013;9(1):e1003160.

Reid MA, Dai Z, Locasale JW. The impact of cellular metabolism on chromatin dynamics and epigenetics. Nat Cell Biol. 2017;19(11):1298306.

Sekido R, Lovell-Badge R. Sex determination involves synergistic action of SRY and SF1 on a specific Sox9 enhancer. Nature. 2008; 453(7197):930-4.

Sinclair AH, Berta P, Palmer MS, Hawkins JR, Griffiths BL, Smith MJ, et al. A gene from the human sex-determining region encodes a protein with homology to a conserved DNAbinding motif. Nature. 1990;346(6281):240-4.

Stevanovic M, Lovell-Badge R, Collignon J, Goodfellow PN. SOX3 is an X-linked gene related to SRY. Hum Mol Genet. 1993;2(12): 2013-8.

Stevant I, Neirijnck Y, Borel C, Escoffier J, Smith LB, Antonarakis SE, et al. Deciphering cell lineage specification during male sex determination with single-cell RNA sequencing. Cell Rep. 2018;22(6):1589-99.

Sutendra G, Kinnaird A, Dromparis P, Paulin R, Stenson TH, Haromy A, et al. A nuclear pyruvate dehydrogenase complex is important for the generation of acetyl-CoA and histone acetylation. Cell. 2014;158(1):84-97.

Sutton E, Hughes J, White S, Sekido R, Tan J, Arboleda $\mathrm{V}$, et al. Identification of SOX3 as an $\mathrm{XX}$ male sex reversal gene in mice and humans. J Clin Invest. 2011;121(1):328-41.
Tachibana M, Sugimoto K, Nozaki M, Ueda J, Ohta T, Ohki M, et al. G9a histone methyltransferase plays a dominant role in euchromatic histone $\mathrm{H} 3$ lysine 9 methylation and is essential for early embryogenesis. Genes Dev. 2002;16(14):1779-91.

Tachibana M, Ueda J, Fukuda M, Takeda N, Ohta $\mathrm{T}$, Iwanari $\mathrm{H}$, et al. Histone methyltransferases G9a and GLP form heteromeric complexes and are both crucial for methylation of euchromatin at H3-K9. Genes Dev. 2005;19(7):815-26.

Tachibana M, Matsumura Y, Fukuda M, Kimura H, Shinkai Y. G9a/GLP complexes independently mediate $\mathrm{H} 3 \mathrm{~K} 9$ and DNA methylation to silence transcription. EMBO J. 2008; 27(20):2681-90.

Takekawa M, Saito H. A family of stress-inducible GADD45-like proteins mediate activation of the stress-responsive MTK1/MEKK4 MAPKKK. Cell. 1998;95(4):521-30.

Tevosian SG, Albrecht KH, Crispino JD, Fujiwara Y, Eicher EM, Orkin SH. Gonadal differentiation, sex determination and normal Sry expression in mice require direct interaction between transcription partners GATA4 and FOG2. Development. 2002;129(19):4627-34.

Thevenet L, Méjean C, Moniot B, Bonneaud N, Galéotti N, Aldrian-Herrada G, et al. Regulation of human SRY subcellular distribution by its acetylation/deacetylation. EMBO J. 2004; 23(16):3336-45.

Turner ME, Martin C, Martins AS, Dunmire J, Farkas J, Ely DL, et al. Genomic and expression analysis of multiple Sry loci from a single Rattus norvegicus Y chromosome. BMC Genet. 2007;8:11.

Wang Y, Deng P, Liu Y, Wu Y, Chen Y, Guo Y, et al. Alpha-ketoglutarate ameliorates age-related osteoporosis via regulating histone methylations. Nat Commun. 2020;11(1):5596.

Warr N, Carre GA, Siggers P, Faleato JV, Brixey R, Pope M, et al. Gadd45 $\gamma$ and Map3k4 interactions regulate mouse testis determination via p38 MAPK-mediated control of Sry expression. Dev Cell. 2012;23(5):1020-31.

Wellen KE, Hatzivassiliou G, Sachdeva UM, Bui TV, Cross JR, Thompson CB. ATP-citrate lyase links cellular metabolism to histone acetylation. Science. 2009;324(5930):1076-80.

Wilhelm D, Martinson F, Bradford S, Wilson MJ, Combes AN, Beverdam A, et al. Sertoli cell differentiation is induced both cell-autonomously and through prostaglandin signaling during mammalian sex determination. Dev Biol. 2005;287(1):111-24.

Wolff GL, Kodell RL, Moore SR, Cooney CA. Maternal epigenetics and methyl supplements affect agouti gene expression in Avy/a mice. FASEB J. 1998;12(11):949-57.

Wu SC, Zhang Y. Active DNA demethylation: many roads lead to Rome. Nat Rev Mol Cell Biol. 2010;11(9):607-20.

Yamane K, Toumazou C, Tsukada Y, ErdjumentBromage $\mathrm{H}$, Tempst $\mathrm{P}$, Wong J, et al. JHDM2A, a JmjC-containing H3K9 demethylase, facilitates transcription activation by androgen receptor. Cell. 2006;125(3):483-95. 